\title{
PRELIMINARY PHYTOCHEMICAL SCREENING AND ANTI-INFLAMMATORY EFFECT OF THE AQUEOUS EXTRACT OF TABERNAEMONTANA DIVARICATA FLOWER IN WISTER RATS
}

\author{
DEEPANKAR GARGA*, TRISHNA DAS \\ Girijananda Chowdhury Institute of Pharmaceutical Science, Azara, Guwahati 781017 \\ Email: dgarga18@gmail.com
}

Received: 20 May 2017, Revised and Accepted: 22 Jul 2017

\section{ABSTRACT}

Objective: To determine the phytochemical analysis and anti-inflammatory effect of the aqueous extract of Tabernaemontanadivaricata flower in Wister Rats.

Methods: The aqueous extract of fresh flowers of the plant Tabernaemontanadivaricata (family-Apocyanaceae) were prepared and analyzed for phytochemical constituents using standard methods. The anti-inflammatory activity of the plant extracts was examined with the help of rat models by taking diclofenac as a standard drug against $T$. divericata oil extract by using carrageenan induced rat paw edema method with the help of the instrument plethesmometer.

Results: The present experiment shows the phytochemical analysis, anti-inflammatory activity of the aqueous extract of fresh flowers of the plant Tabernaemontanadivaricata (family-Apocyanaceae). Various phytochemical analysis revealed the presence of saponins, flavonoids, glycosides, steroids, proteins, phenols, amino acids and tannins. The oil extract of the plant showed much effective anti-inflammatory activity against the standard drug.

Conclusion: It can be concluded aqueous extract of the flower of the plant Tabernaemontanadivaricata (family-Apocyanaceae) contain the high presence of phytochemicals. This extract was found to possess promising antimicrobial activity when compared with the standards.

Keywords: Tabernaemontanadivaricata, Phytochemicals, Rat paw edema, Anti-inflammatory

(C) 2017 The Authors. Published by Innovare Academic Sciences Pvt Ltd. This is an open access article under the CC BY license (http://creativecommons.org/licenses/by/4.0/) DOI: http://dx.doi.org/10.22159/ijcpr.2017v9i5.22128

\section{INTRODUCTION}

Modern allopathic drugs which are single active components that target one specific pathway, herbal medicines work in a way that depends on an orchestral approach. A plant contains a multitude of different molecules that act synergistically on targeted elements of the complex cellular pathway. Medicinal plants have been a source of a wide variety of biologically active compounds for many centuries and used extensively as crude material or as pure compounds for treating various disease conditions. The use of herbal medicines becoming popular due to toxicity and side-effects of allopathic medicines. Medicinal plants play an important role in the development of potent therapeutic agents. There are over 1.5 million practitioners of the traditional medicinal system using medicinal plants in preventive, promotional and curative applications. India has a very long, safe and continuous usage of many herbal drugs in the officially recognized alternative systems of health viz. Ayurveda, Yoga, Unani, Siddha, Homeopathy and Naturopathy [1].

According to the World Health Organization (WHO), about 70-80\% of the world populations, particularly in the developing countries, rely on non-conventional medicine mainly of herbal sources in their primary healthcare [2]. In spite of the great advances observed in modern medicine in recent decades, plants still make an important contribution to health care. Medicinal plants are distributed worldwide, but they are most abundant in tropical countries. Over the past decade, interest in drugs derived from higher plants, especially the phytotherapeutic ones, has increased expressively. It is estimated that about $25 \%$ of all modern medicines are directly or indirectly derived from higher plants [3].

Inflammation is the response of living tissue to injury. It involves a wellorganized cascade of fluidic and cellular changes. It is recognizable grossly and histologically and has both beneficial and detrimental effects locally and systemically. Inflammation are mainly of two types acute and chronic. Acute inflammation usually has to become within minutes or at most hours after tissue injury and may be characterized by the classical symptoms of redness, heat, and edema. It's a short term process. Chronic inflammation is of a more prolonged duration and histologically by the presence of lymphocytes and macrophages, resulting in fibrosis and tissue necrosis. The chronic inflammation increases the development of the degenerative diseases such as rheumatoid arthritis, atherosclerosis, heart disease etc [4].

Tabernaemontanadivaricata (L.) R. Br. (Synonyms: Ervatamiacoronaria, E. microphylla, E. divaricata, T. coronaria) belongs to family Apocynaceae. The common vernacular names are Crepe Jasmine, Carnation of India, East Indian Rosebay and Pinwheel Flower (English), Nandivrksha (Sanskrit), Chandni (Hindi), Kathanda (Assamese). T. divaricata is glabrous, evergreen shrub 1.8-2.4 $\mathrm{m}$ in height with silvery grey bark and milky latex; leaves are simple, opposite, elliptic or elliptic-lanceolate, smooth, glossy green, acuminate and wavy margins; flowers are white, sweetly fragrant in 1-8 flowered cymes at the bifurcations of the branches, lobe of corolla overlapping to right in the bud; fruit follicles are 2.5-7.5 cm long, ribbed and curved, orange or bright red within narrowed into a slender curved beak; seeds are dull brown, minutely pitted, irregular, enclosed in a red pulpy aril [5]. This plant is traditionally used by people in many parts of the world to treat various disorders like abdominal tumors, arthralgia, asthma, diarrhea, epilepsy, eye infections, fever, fractures, headache, inflammation, leprosy, mania, edema, paralysis, piles, rabies, rheumatic pain, skin diseases, ulceration and vomiting. It is also used as anthelmintic, antihypertensive, aphrodisiac, diuretic, hair growth promoter, purgative etc [6].

\section{MATERIALS AND METHODS}

\section{Collection of the plant}

The plant material Tabernaemontanadivericata flowers were collected in the month of January-March from local areas of Assam. The plant species were identified and authenticated at The Dept of Botany, Gauhati University. (Acc. No.18214 dated 22.12.2016)

\section{Extraction of plant}

The Clevenger Apparatus conducts the distillation process by boiling, condensing and decantation to separate the oil. This is also 
the official standard method for extracting essential oils for quality control. So, firstly the fresh flowers are collected and put inside the round bottom flask and pour some water up to an optimum level and then the apparatus is fixed and the temperature is maintained from $40-50{ }^{\circ} \mathrm{C}$ then extracted for $6-7 \mathrm{~h}$ for the extraction of volatile oil [7].

\section{Experimental animals}

Healthy Wister albino rats weighing $180-190 \mathrm{~g}$ of either sex were used for the study. The animals were procured and housed in the animal house of Girijananda Institute of Pharmaceutical Science at least 1 months prior to the study so that animal could adapt to the new environment. Animal house was well maintained under the standard hygienic conditions, at a temperature $\left(22 \pm 2{ }^{\circ} \mathrm{C}\right)$, room humidity $(60 \pm 10 \%)$ with $12 \mathrm{~h}$ day and night cycle, with food and water ad libitum. Rats were housed in groups of 4 per cage.

Each group comprised of 2 rats each:

Group I: Control group. (Saline Water)

Group II: Standard group (Diclofenac Sodium)

Group III: Test group (Oil of Tabernaemontanadivericata

\section{Acute toxicological studies}

Acute toxicity test was carried out as per the guideline set by the Organization for Economic Co-operation and Development (OECD guidelines 425) received from the Committee for the Purpose of Control and Supervision of Experiments on Animals (CPCSEA). To establish the safety of the extracts (methanolic and chloroform) administered to both male and female mice. We observed no significant toxic signs or death during the $14 \mathrm{~d}$ observation period. None of the mice showed clinical toxic signs such as anorexia, depression, lethargy, jaundice, dermatitis and also, no mortality happened throughout the examination. As the result for acute toxicity studies was already been reported, hence the obtained result is been used as a reference from review papers [8].

\section{Preliminary phytochemical screening [9-11]}

Phytochemical examinations were carried out for the oil extract as per the standard methods:

\section{$>$ Detection of alkaloids}

Extracts were dissolved individually in dilute Hydrochloric acid and filtered.

\section{a) Mayer's test}

Filtrates were treated with Mayer's reagent (Potassium Mercuric Iodide). Formation of a yellow coloured precipitate indicates the presence of alkaloids.

\section{b) Wagner's test}

Filtrates were treated with Wagner's reagent (Iodine in Potassium Iodide). Formation of brown/reddish precipitate indicates the presence of alkaloids.

\section{c) Dragendroff's test}

Filtrates were treated with Dragendroff's reagent (solution of b Potassium Bismuth Iodide). Formation of red precipitate indicates the presence of alkaloids. d) Hager's Test: Filtrates were treated with Hager's reagent (saturated picric acid solution). Presence of alkaloids confirmed by the formation of a yellow coloured precipitate.

\section{$>$ Test for glycosides \\ a) Cardiac glycoside}

\section{Keller-killiani test}

To $2 \mathrm{ml}$ of extract, glacial acetic acid, one drop $5 \%$ ferric chloride and concentrated sulphuric acid were added. The appearance of reddish brown colour at the junction of the two liquid layers indicates the presence of cardiac glycosides.

\section{b) Anthraquinone glycosides}

\section{Borntrager's test}

To $3 \mathrm{ml}$ extract dilute sulphuric acid was added, boiled and filtered. To the cold filtrate, equal volume benzene or chloroform was added. The organic layer was separated and ammonia was added. Ammonical layer turns pink or red.

\section{$>$ Test for phenolic compounds}

\section{Ferric chloride test}

Extracts were treated with 3-4 drops of ferric chloride solution. Formation of bluish black colour indicates the presence of phenols.

\section{$>$ Test for proteins}

Various extracts were dissolved in few $\mathrm{ml}$ of water and treated with

\section{a) Millon's reagent}

Appearance of red colour shows the presence of proteins and free amino acids.

\section{b) Biuret test}

An equal volume of $5 \%$ solution of sodium hydroxide and $1 \%$ copper sulphate were added. Appearance of pink or purple colour indicates the presence of proteins and free amino acids.

\section{$>$ Test for steroids}

\section{a) Libermann-burchard reaction}

To $2 \mathrm{ml}$ extract was mixed with chloroform. To this $1-2 \mathrm{ml}$ acetic anhydride and 2 drops concentrated sulphuric acid were added from the side of the test tube. First red, then blue and finally green colour appears.

\section{b) Salkowski reaction}

To $2 \mathrm{ml}$ extract was mixed with $2 \mathrm{ml}$ of chloroform and $2 \mathrm{ml}$ conc. Sulphuric acid. Shake well. Chloroform layer appears red and acid layers shows greenish yellow fluorescence.

\section{$>$ Test for tannins}

\section{Gelatin test}

To the extract, $1 \%$ gelatin solution containing sodium chloride was added. Formation of white precipitate indicates the presence of tannins.

\section{$>$ Detection of Flavonoids}

\section{(a) Shinoda's test}

The extracts were dissolved in alcohol, to that a piece of magnesium and followed by concentrated hydrochloric acid was added drop wise and heated. Appearance of magenta colour shows the presence of flavonoids.

\section{(b) Lead acetate test}

Extracts were treated with few drops of lead acetate solution. Formation of yellow colour precipitate indicates the presence of flavonoids.

\section{Anti-inflammatory activity \\ Carrageenan induced acute rat paw edema}

Inflammation was induced by injecting $1.0 \%$ carrageenan solution subcutaneously into the sub-plantar tissue of the right hind paw. The first group served as control and received normal saline. The second group was administered with diclofenac sodium gel as the standard drug. The third group received the aqueous extract of Tabernemontanadivericata flowers. The extracted oil was administered topically $60 \mathrm{~min}$ prior to injection of carragenan. The initial volume $\left(\mathrm{V}_{0}\right)$ of the right hind paw of each rat was measured before and then followed by $1,2,3,4,5,6 \mathrm{~h}$ after administration of the phlogistic agent. The volume of paw edema was measured with the help of plethysmograph by mercury displacement method and 
the percentage of anti-inflammatory activity was calculated. The paw edema rate and inhibition rate of each group were calculated using the formula:

$\%$ Inhibition $=\left(\mathrm{C}_{\mathrm{t}}-\mathrm{C}_{\mathrm{o}}\right)$ control $-\left(\mathrm{C}_{\mathrm{t}}-\mathrm{C}_{\mathrm{o}}\right)$ treated $/\left(\mathrm{C}_{\mathrm{t}}-\mathrm{C}_{\mathrm{o}}\right)$ control $\mathrm{x} 100$

Where $\mathrm{Ct}=$ paw circumference at time $\mathrm{t}$, Co $=$ paw circumference before carrageenan injection, $(\mathrm{Ct}-\mathrm{Co})=$ oedema or change in paw size after time $\mathrm{t}$ [12-13].

Each group comprised of 2 rats each:

Group I: Control group. (Saline Water)

Group II: Standard group (Diclofenac Sodium)

Group III: Test group (Oil of Tabernaemontanadivericata)

\section{RESULTS}

In this section, the results of various investigations carried out were compiled. An attempt has also been made to discuss these results, in order to provide convincing reasons for the studies performed.

\section{Physico-chemical parameters}

$>$ Physical test for volatile oil

- It has a characteristic odour.

- The filter paper is not permanently stained.

- Solubility test: Soluble in $90 \%$ alcohol.

- ph-5.2

Preliminary phytochemical analysis of oil of Tabernaemontanadivericata

From the phytochemical analysis of the crude aqueous extract of Tabernaemontanadivericata flower found to consist of phytochemicals like saponins, flavonoids, glycosides, steroids, proteins, phenols, amino acids and tannins.

\section{Anti-inflammatory study}

The anti-inflammatory effect of Tabernaemontanadivericata flower extract which is compared with the standard drug are shown in table 1.

Table 1: The anti-inflammatory effect of Tabernaemontanadivericata flower extract which is compared with the standard drug

\begin{tabular}{|c|c|c|c|c|c|c|c|}
\hline & \multicolumn{7}{|c|}{ Paw volume (ml) } \\
\hline & $\mathbf{0 ~ h}$ & $1 \mathrm{~h}$ & $2 \mathrm{~h}$ & $3 \mathbf{h}$ & $4 \mathrm{~h}$ & $\mathbf{5 h}$ & $6 \mathrm{~h}$ \\
\hline Control (Carageenan) & $2.33 \pm 0.23$ & $2.67 \pm 0.33$ & $2.72 \pm 0.32$ & $2.76 \pm 0.33$ & $2.7 \pm 0.23$ & $2.69 \pm 0.33$ & $2.63 \pm 0.23$ \\
\hline Standard (Diclofenac gel) & $3.83 \pm 0.27$ & $4.10 \pm 0.43$ & $3.97 \pm 0.47$ & $3.87 \pm 0.32$ & $3.85 \pm 0.44$ & $3.83 \pm 0.32$ & $3.79 \pm 0.27$ \\
\hline Test (Oil extract of T. divericata flower) & $3.43 \pm 0.21$ & $3.53 \pm 0.32$ & $3.67 \pm 0.33$ & $3.6 \pm 0.44$ & $3.5 \pm 0.34$ & $3.47 \pm 0.27$ & $3.4 \pm 0.21$ \\
\hline
\end{tabular}

Values are expressed as mean $\pm \mathrm{SEM},{ }^{*} \mathrm{P}<0.05$, significantly different from control, (One way ANOVA followed by Dunnett's test)

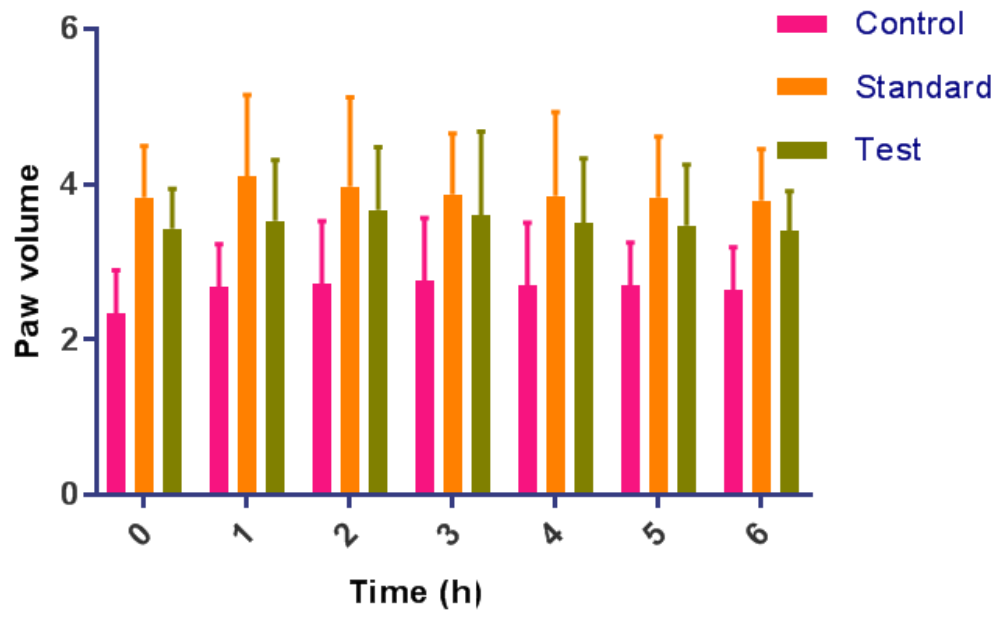

Fig. Graph showing anti-inflammatory activity by carrageenan induced rat paw edema

\section{DISCUSSION}

The physicochemical constants like moisture constant, ash values such as total ash, acid insoluble ash, water soluble ash, extractive values such as water soluble extractive value and alcohol soluble extractive value were determined. These help in formulating pharmacopoeial standards for the drug.

Fluorescence analysis was also carried. The powder as such showed light yellow color in visible as well as in short wave light. This study helps in distinguishing the drug in powder form.

Furthermore, the preliminary photochemical screening of aqueous oil extract of the plant showed the presence of saponins, flavonoids, tannins, proteins, amino acids, and phenols.

Anti-inflammatory of aqueous extract of $T$. divericata flower was evaluated by using Carrageenan induced rat paw edema (Topically) with the help of Plethesmometer with the objective of identifying possible anti-inflammatory effects of the test substances. Carrageenan induced paw edema in the rat is used as a standard model of screening for anti-inflammatory activity. Carrageenan is commonly used due to the absence of apparent systemic effects, antigenic nature and highly reproducing. It causes edema by enhancement of inflammatory mediators that increase vascular permeability and/or increase blood flow and is believed to be biphasic. After performing the activity the volatile oil of $T$. divericata flower show much effective result than the standard drug when applied topically [14].

\section{CONCLUSION}

In the present study, phytochemical and pharmacological tests were performed and it indicates that the investigated plant is having antiinflammatory activity. The anti-inflammatory was done using Carrageenan induced rat paw edema in Wister albino rats.

Hence, from our overall investigation, it can be concluded that $T$. divericata flower possesses anti-inflammatory activity. Therefore, 
further studies are needed for the isolation and identification of the active principle responsible for these properties, which can give rise to new drug molecule.

\section{CONFLICT OF INTERESTS}

Declare none

\section{REFERENCES}

1. Doe C, Bentley R, Behm DJ, Lafferty R, Stavenger R, Jung D, et al. Novel rho kinase inhibitors with anti-inflammatory and vasodilatory activities. J Pharmacol Exp Ther 2007;320:89-98.

2. Akerele 0 . Nature's medicinal bounty: don't throw it away. World Health Forum 1993;14:390-5.

3. Calixto JB. Efficacy, safety, quality control, marketing and regulatory guidelines for herbal medicines (phytotherapeutic agents). Braz J Med Biol Res 2000;33:179-89.

4. Menkin V. Biochemical mechanisms in inflammation. Br Med J 1960;1:1521.

5. Warrier PK, Nambiar VPK, Ramankutty C. Indian medicinal plants. Vol. II. Madras: Orient Longman Ltd; 1996. p. 232.

6. Pratchayasakul W, Pongchaidecha A, Chattipakorn N, Chattipakorn S. Ethnobotany and ethnopharmacology of Tabernaemontanadivaricata. Indian J Med Res 2008;127:317-35.

7. Evans WC. Trease and Evans. Pharmacognosy. 15th ed. Toronto: Harcourt Pub Ltd; 2002. p. 1-40.
8. Kandati. In vitro and in vivo anti-inflammatory activity of Andrographisserpyllifolia. Int Curr Pharm J 2012;1:199-204.

9. Khandelwal KR. Practical pharmacognosy techniques and experiments. India: Nirali Prakashan; 2010. p. 12-30, 32.

10. CK Kokate. Practical Pharmacognosy. Vallabh Prakashan. 4th edn. 14. Delhi; 2005. p. 178-82.

11. JB Harborne. Phytochemical methods. 3rd ed. London: Chapman and Hall; 1998.

12. Qamruzzamaa, Javed Akhtar Ansarib. Analgesic and antiinflammatory effect of ethanolic extract of Tabernaemontanadivaricata L. flowers in rats. Scholar Res Library 2012;4:1518-22.

13. Arawwawala M, Thabrew I, Arambewela L, Handunnetti S. Anti-inflammatory activity of Trichosanthescucumerina Linn. in rats. J Ethnopharmacol 2010;131:538-43.

14. Ramachandran S, Rajinikanth B, Rajasekaran A, Manisenthil Kumar KT. Evaluation of anti-inflammatory and analgesic potential of methanol extract of Tectonagrandis flowers. Asian Pac J Trop Biomed 2011;1 Suppl:S155-S158.

\section{How to cite this article}

- Deepankar Garga, Trishna Das. Preliminary phytochemical screening and anti-inflammatory effect of the aqueous extract of Tabernaemontana divaricata flower in wister rats. Int J Curr Pharm Res 2017;9(5):9-12. 